\title{
ANALISIS CERPEN PARTA KRAMA KARYA UMAR KAYAM MENURUT REPERTOIRE ISER
}

\author{
Oleh: Sudibyo*
}

\begin{abstract}
Abstrak
Cerpen Parta Krama dapat dipahami sebagai upaya Umar Kayam untuk mempertegas pendirianny'a mengenai keharusan dan keberanian menyatakan something is rotten in the state jika di dalam negara benar-benar ada sesuatu yang membusuk. Di samping itu, Umar Kayam juga ingin mengungkapkan kendala-kendala penerapan pola high living (kehidupan luhur) yang di tengah-tengah masyarakat yang dikendalikan oleh uang (arta) menjadi sangat berat karena kekayaan dan uang adalah segala-galanya.

Cerpen Parta Krama adalah sebuah parodi dan kritik sosial tanpa pemihakan, tanpa maksud menggurui, serta tanpa tendensi menghakimi. Parta Krama mengalir begitu saja membawa muatannya tanpa campur tangan pengarang. Dengan demikian, dapat dikatakan bahwa Parta Krama berbicara mengenai dirinya sendiri. Dari sini, terlihat bahwa pengarang secara ketat memelihara distansi dengan apa yang dikemukakannya melalui cerpen Parta Krama.

Cerpen Parta Krama telah secara kreatif menginterpretasi, mereduksi, dan menstransformasikan repertoire-repertoire-nya, seperti lakon wayang Parta Krama dan sistem norma-norma sosiokultural yang melibatkan praktik kolusi, korupsi, dan pembusukan hukum. Semua ini ditunjukkan melalui perspektif narator, tokoh cerita, dan pembaca dengan memanfaatkan strategi yang salah satu fungsinya adalah mendefamiliarisasikan apa-apa yang sudah familiar. Dengan cara demikian, cerpen Parta Krama bukan imitasi lakon wayang Parta Krama. Tegangan antara Parta Krama dan bukan Parta Krama ini. dari perspektif pembaca justru melahirkan efek estetik.
\end{abstract}

\section{A. Pendahuluan}

Sebagai seorang cerpenis dan novelis, Umar Kayam tidak dapat dikatakan produktif. Namun, dari beberapa buah cerpen, dua buah cerpen panjang, dan sebuah novel yang ditulisnya, Umar Kayam mampu menunjukkan kelasnya dalam jajaran para pengarang sastra Indonesia.

\footnotetext{
- Dosen Jurusan Sastra Indonesia Fakultas Sastra Univeersitas Gadjah Mada Yogyakarta
} 
Dalam cerpen-cerpennya yang awal yang terkumpul dalam Seribu Kunang-Kunang di Manhattan, melalui cerpen Istriku, Madame Schlitz, dan Sang Raksasa, serta cerpen Secangkir Kopi dan Sepotong Donat, Umar Kayam berhasil mendemonstrasikan kepiawaiannya dalam menulis cerpen. Apabila dibandingkan dengan cerpen-cerpen berlatar luar negeri yang lain, yang pernah ditulis oleh Budi Darma, Kuntowijoyo, Satyagraha Hoerip, dsb., cerpen-cerpen Umar Kayam tampak lebih unggul. Keunggulannya, terletak pada kemampuannya membebaskan diri dari muatan filsafat, gagasan, dan cara pandang yang dingin. Di samping itu, kecermatannya dalam memotret situasi, yaitu kehidupan keseharian orang-orang metropolis di Amerika sulit ditandingi, dan hal lain yang sangat penting, semua itu digambarkan dengan cara main-main (Faruk, 1997)

Khusus tentang cerpen Secangkir Kopi dan Sepotong Donat, Ajidarma (1997: 7-8), menyampaikan pujiannya. Pertama, menurut Ajidarma, cerpen yang hanya berlangsung satu jam, dari pukul 10.00 sampai dengan pukul 11.00 itu mampu menggambarkan suatu potret masyarakat modern. Kedua, dari segi struktur, cerpen itu memiliki struktur yang kuat, Secangkir Kopi dan Sepotong Donat adalah sebuah cerpen yang akan selalu kontemporer dan selalu modern melalui teknik bercerita tanpa cerita. Cerpen ini juga memiliki selera bertutur yang sangat canggih.

Dalam karya-karyanya yang lebih kemudian, yang dalam tulisan ini akan disebut sebagai karya tahap kedua, melalui dua cerpen panjang Sri Sumarah dan Bawuk serta novel Para Priyayi, Umar Kayam lebih menampakkan sosoknya sebagai pengamat kehidupan sosial yang amat teliti. Ketiga cerita itu, secara kebetulan, menggambarkan proses perubahan sosial yang terjadi di kalangan priyayi rendahan, yaitu kalangan guru.

Dalam Sri Sumarah dan Bawuk, Umar Kayam mengangkat tema yang amat peka pada masanya dan bahkan sampai sekarang, yaitu permasalahan di seputar peristiwa pemberontakan G 30 S PKI. Melalui tokoh Tun (Sri Sumarah) dan Bawuk (Bawuk), Kayam Menampilkan dua sosok progresif-revolusioner yang dihadapkannya dengan figur-figur priyayi Jawa yang sumarah dan legawa seperti Sri Sumarah dan Nyonya Suryo. Digerakkan oleh sikap progresif-revolusioner yang ditunjukkan oleh Tun dan Bawuk dalam menerima ajaran komunis, serta sikap sumarah dan legawa Sri Sumarah dan Nyonya Suryo dalam menghadapi segala kenyataan yang terjadi atas anak-anaknya, cerita Sri Sumarah dan Bawuk menjadi sangat 
signifikan. Kedua cerita ini sama sekali tidak terasa SARA meskipun berusaha mengungkapkan persoalan peka sebagaimana disebut di atas karena Kayam hanya melakukan pemihakan secara samar-samar atau sama sekali tidak berpihak (Faruk, 1997). Hal ini dimungkinkan karena Kayam dengan meminjam terminologi Ricoeur (1991: 47) mampu memelihara jarak (verfremdung) dari keterlibatannya (zugehorigkeit).

Persoalan perubahan sosial diangkat lagi oleh Umar Kayam secara lebih rinci dalam novel Para Priyayi. Novel yang oleh beberapa kritisi sastra dianggap berada pada ambang teks ilmu sosial dan karya fiksi ini, sebagaimana halnya dengan Sri Sumarah dan Bawuk, juga memotret perubahan sosial yang terjadi di kalangan para priyayi rendah yang terjadi di suatu pseudolokasi bernama Wanagalih, sebuah ibu kota kabupaten di Jawa Timur. Melalui tokoh-tokoh ceritanya, seperti Sastrodarsono, Lantip, Noegroho, Hardojo, Harimurti, dsb., Para Priyayi melukiskan problemproblem sebuah keluarga yang bergerak dari masyarakat berdasarkan status (priyayi) menuju masyarakat kelas (pegawai negeri) di sekitar 1910 sampai dengan 1967. Novel ini bercerita tentang perubahan dari waktu ke waktu, tentang sebuah keluarga, dan peristiwa mobilitas sosial dengan segala permasalahannya (Kuntowijoyo, 1997:1).

Pilihannya menempatkan guru yang notebene adalah priyayi rendah, menjadikan Para Priyayi terasa unik. Karena kendati guru adalah yang terendah dalam stratifikasi priyayi, ia berkedudukan tinggi dalam percaturan masyarakat lokal di tingkat desa. Guru adalah agen perubahan yang cukup penting karena ia adalah agen perubahan sosial, politik, dan ekonomi (Dhakidae, 1997: 5). Kekuatan ini menjadikan Para Priyayi terasa orisinal.

Setelah penulisan Para Priyayi (1992), beberapa tahun, Umar Kayam dapat dikatakan vakum dari penulisan karya sastra. Baru, pada 19961997, Kayam mempublikasikan cerpen-cerpen berjudul Sphinx (Kompas, 15 September 1996), diikuti Raja Midas (Kompas, 22Desember 1996), Parta Krama (Kompas, 23 Februari 1997), dan Drs. Citraksi \& Drs. Citraksa (Kompas, 15 Juni 1997). Keempat buah cerpen yang ditulis pada kurun tahun 1996-1997 ini merupakan cerpen-cerpen yang menarik apabila dikaitkan dengan fase perkembangan kepengarangan Umar Kayam. Berbeda dengan cerita-cerita yang ditulis pada fase sebelumnya, terutama Sri Sumarah dan Bawrek (1975) dan Para Priyayi (1992) yang mengungkapkan peristiwa yang telah menyejarah, keempat cerpen tersebut mengungkapkan problem- 
problem aktual yang sedang terjadi di tengah masyarakat, seperti kekakuan birokrasi yang menyebabkan masyarakat berinteraksi tanpa sentuhan emosi dan tanpa keterlibatan empati (Sphinx); usaha seseorang untuk menundukkan kolega-koleganya secara tidak jujur, yaitu dengan cara memberi suap, setelah kolega-koleganya tersebut mengetahui bahwa ia bertindak di luar batas kemampuannya (Raja Midas); kolusi, korupsi, dan pembusukan hukum (Parta Krama); serta nepotisme dan kegagapan birokrat koneksi dalam menghadapi mobilitas sosial (Drs. Citraksi \&Drs. Citraksa). Tampaknya, cerpen-cerpen tersebut di atas ditulis pada saat Kayam perlu menyampaikan refleksi. Tanpa bermaksud menggurui, melalui cerpen-cerpen tersebut, Kayam berusaha menyampaikan gagasan-gagasannya tentang high living (kehidupan luhur) yang menurutnya sangat penting meskipun kendalanya sangat berat karena di dalam masyarakat yang dikendalikan uang, kekayaan merupakan hal yang sangat penting. Sehubungan dengan itu, menurut Kayam (1996), supaya manusia dapat berpikir canggih, hidupnya harus bersih. Nuraninya sebagai individu dan sebagai warga bangsa harus terus-menerus dilatih. Jika perlu, ia harus berani mengatakan something is rotten in the state sebagai wujud tanggung jawab dan kepeduliannya (Kayam, 1991: 13). Bertolak dari sini, tanpa pamrih yang bersifat tendensius, kayam melalui keempat cerpen di atas mencoba untuk mengatakan something is rotten. Namun demikian, ia tetap tidak berpihak atau kalau berpihak, keberpihakan itu sangat samar-samar. Ia cukup piawai mempertahankan distansi sehingga sama sekali tidak melakukan justifikasi.

Kemampuan Kayam melakukan distansiasi dalam cerita-cerita yang ditulisnya berhubungan dengan kedudukannya sebagai ilmuwan yang senantiasa dituntut berpandangan objektif, sedangkan kejeliannya dalam memotret peristiwa, tak dapat disangsikan, dilatari oleh disiplin ilmu yang ditekuninya, yaitu sosiologi dan antropologi. Semua ini bersama dengan kepriyayiannya yang diyakininya memiliki kewajiban berempati dan mengentaskan wong cilik (Kayam, 1997: 61) serta yang disyukurinya sebagai bagian integral dari sejarah sosial Indonesia justru merupakan kekuatan dan aset bagi cerita-cerita Kayam.

Di dalam tulisan ini, secara khusus, akan dianalisis cerpen Parta Krama berdasarkan teks terbitan Kompas, 23 Februari 1997. Adapun untuk alat analisis dipergunakan Teori Respons Estetik, terutama teori mengenai repertoire yang mendasari penciptaan karya sastra sebagaimana yang 
dikemukakan Wolfgang Iser dalam bukunya The Act of Reading: A Teory of Aesthetic Response terbitan The John Hopkins University Press, 1987, halaman 53--103. Pemilihan teori ini didasari anggapan bahwa di antara keempat cerpen di atas, cerpen Parta Krama-lah yang paling kuat membayangkan hal-hal yang diungkapkan dalam teori repertoire. yaitu adanya latar belakang yang dijadikan sebagai dasar pijakan penciptaan cerpen Parta Krama.

\section{B. Landasan Teori}

Repertoire terdiri atas keseluruhan wilayah yang dikenal di dalam teks. Repertoire dapat berupa referensi-referensi kepada karya-karya sebelumnya, norma-norma sosial dan historis, atau keseluruhan kebudayaan yang darinya teks berasal. Fakta yang diacu oleh realitas-realitas di atas memiliki implikasi ganda, yaitu: (1) realitas yang dibangkitkan tidak terbatas pada halaman tercetak, dan (2) unsur-unsur tersebut memilih referensi tidak direncanakan sebagai tiruan semata-mata. Akan tetapi, kehadiran unsur-unsur di dalam teks biasanya berarti bahwa unsur-unsur tersebut melalui semacam transformasi. Unsur-unsur tersebut juga direduksi dan dimodifikasi sebagaimana unsur-unsur tersebut disingkirkan dari fungsi dan konteks orisinalnya (Iser, 1987:69).

Repertoire tersusun dari seleksi norma-norma dan alusi-alusi (Iser, 1987: 70). Komponen dasarnya lahir dari interaksi antara karya sastra dengan sistem pemikiran historis. Bagi pembaca kontemporer, tafsiran terhadap norma-norma yang mengisi repertoire akan membuatnya melepaskan normanorma ini dari konteks sosial dan kultural. Dengan demikian, ia mengakui keterbatasan-keterbatasan efektivitas norma-norma tersebut (Iser, 1987: 78).

Repertoire teks sastra tidak terdiri atas norma-norma sosial sematamata, tetapi juga mencakup unsur-unsur dan keseluruhan tradisi sastra masa lampau yang teramu bersama-sama dengan norma ini. Dapat dikatakan bahwa proporsi ramuan ini merupakan dasar perbedaan di antara genre-genre sastra. Di dalam hal ini, ada teks yang menitikberatkan pada faktor empiris dan faktor-faktor tertentu sehingga menumbuhkan proporsi norma-norma ekstra tekstual dalam repertoire. Di pihak lain, ada juga teks yang repertoirenya didominasi oleh unsur-unsur yang berasal dari karya sastra yang sudah ada pada masa sebelumnya (Iser, 1987: 79). 
Alusi-alusi sastra yang melekat pada repertoire dan yang kemudian dilepaskan dari konteks orisinalnya menjelaskan bahwa alusi-alusi itu tidak hanya dimaksudkan sebagai reproduksi semata-mata: Pendeknya, alusi-alusi tersebut mengalami depragmatisasi dan ditempatkan dalam suatu konteks yang baru. Namun demikian, tidak lantas berarti bahwa konteks lama lenyap sama sekali. Sebaliknya, konteks lama itu ditransformasikan ke dalam latar belakang yang sebenarnya, yang terhadapnya persoalan baru dapat tampil secara jelas dan menonjol (Iser, 1987:79-80).

Unsur-unsur yang berbeda dari repertoire sastra memasok panduan bagi dialog antara teks sastra dengan pembaca. Panduan ini menjadi esensial dipandang dari keseluruhan fungsi teks dalam memberikan suatu jawaban. Semakin kompleks permasalahan yang harus dijawab, panduannya pun akan semakin terdeferensiasi. Teks kesastraan harus mencakup situasi historis yang lengkap yang terhadapnya teks itu sendiri bereaksi. Norma-norma sosial dan kultural yang membentuk situasi ini perlu diorganisasikan sedemikian rupa sehingga alasan penyeleksian norma-norma tersebut dapat disampaikan kepada pembaca. Namun, karena hal ini tidak dapat disampaikan secara eksplisit, kecuali jika fiksi diubah menjadi dokumenter, harus ada cara untuk menggeneralisasikan repertoire. Di sinilah letak fungsi khusus alusi-alusi kesastraan (Iser, 1987:80).

Repertoire mencakup unsur-unsur utama yang secara tradisional disebut "isi". Oleh sebab itu, repertoire membutuhkan suatu "bentuk" atau suatu "struktur" untuk mengorganisasikan suatu kehadirannya (Holub, 1989: 88). Iser menggunakan istilah "strategi" untuk menyebut fungsi ini. Strategi, menurut Iser (1989:86), meliputi baik struktur imanen teks maupun tindaktindak pemahaman yang digerakan pembaca. Akan tetapi, perlu diingat bahwa strategi bukanlah teknik-teknik naratif tradisional atau sarana retiris karena kesemua itu hanyalah merupakan fenomena permukaan teks. Strategi adalah struktur-struktur yang mendasari teknik-teknik superfisial semacam itu dan memungkinkan struktur-struktur tersebut memiliki suatu efek (Holub, 1989: 88)

$\mathrm{Di}$ antara fungsi-fungsi strategi, fungsi terpenting adalah mendefamiliarisasikan hal-hal yang familiar (Iser, 1987:87). Adapun struktur-struktur yang mengaturnya adalah latar depan (foreground) dan latar belakang (background), serta tema dan horison. Latar depan dan latar belakang mengendalikan persepsi pembaca dan bertanggung jawab bagi 
makna karya sastra. Latar depan dan latar belakang merupakan struktur dasar yang melaluinya strategi-strategi teks menciptakan suatu tegangan yang membawa kepada serangkaian tindakan dan interaksi yang berbeda, dan yang pada akhirnya diputuskan dengan kemunculan objek estetik (Iser, 1987: 95).

Tema dan horison melibatkan seleksi terhadap perspektif-perspektif ganda dalam sebuah teks (Holub, 1989: 88). Pada umumnya, ada empat perspektif yang dapat memunculkan pola repertoire, yaitu perspektif narator, tokoh, alur, dan perspektif pembca. Namun demikian, teks-teks naratif tidak harus selalu melibatkan keempat perspektif ini (Iser, 1987: 96).

Berdasarkan pada apa yang dikemukan oleh Iser tentang repertoire di atas, dapat disimpulkan bahwa repertoire berhubungan erat dengan bekal yang dimiliki pembaca ketika berhadapan dengan karya sastra. Bekal ini dapat berupa pengetahuan tentang karya-karya sastra sebelumnya, normanorma sosial dan historis, serta keseluruhan kebudayaan tempat teks berasal. Bekal ini sangat menentukan pemahaman, ketika seorang pembaca berinteraksi dengan teks sastra yang tengah dibacanya, sedang apabila pembaca kemudian berposisi sebagai seorang penulis karya sastra, bekal ini juga turut menentukan karya sastra yang diciptakannya.

Bertolak dari simpulan di atas, rasanya tidak terlalu berlebihan jika dikatakan bahwa lakon wayang Parta Krama beserta seluruh aspek kebudayaan Jawa yang melatarbelakanginya merupakan repertoire yang sangat signifikan bagi penulisan cerpen Parta Krama. Alasannya sederhana. Judul cerpen Parta Krama membangkitkan alusi terhadap lakon wayang Parta Krama. Di samping itu, judul yang dinyatakan dalam bahasa Jawa Parta Krama yang berisi "Perkawinan Parta atau Arjuna" membayangkan sistem budaya yang mengkontruksikannya, yaitu kebudayaan Jawa.

Oleh karena merupakan cerpen kontemporer, cerpen Parta Krama tidak sepenuhnya mengikuti lakon wayang Parta Krama. Cerpen Parta Krama berusaha menginterpretsikan, mereduksi, dan mentransformasikan lakon Parta Krama ke dalam kehidupan kekinian. Untuk itu, repertoire lain berupa norma-norma sosiokultural yang di dalamnya terdapat problemproblem aktual, seperti tindakan korupsi, kolusi, dan pembusukan hukum pun dimanfaatkan untuk memberi aksentuasi cerpen kehidupan masa kini. Dengan cara demikian, cerpen Parta Krama tidak dapat disamakan dengan lakon wayang Parta Krama. 


\section{Analisis terhadap Repertoire Cerpen Parta Krama}

Cerpen Parta Krama ditulis ketika ingatan orang di Indonesia terhadap peristiwa kolusi antara seorang pengusaha keturunan Cina dengan sebuah bank ternama milik pemerintah masih cukup kuat. Dalam peristiwa itu terlibat sejumlah pejabat penting di bank tersebut, bahkan lebih dari itu beberapa pejabat tinggi negara ikut terlibat.

Ketika dilakukan pengusutan terhadap peristiwa kolusi dan korupsi yang mengakibatkan negara mengalami kerugian sebesar 1,3 triliun rupiah tersebut, sejumlah pejabat tinggi yang menurut opini umum terlibat, tidak tersentuh sanksi hukum. Para pejabat yang diajukan ke meja hijau hanyalah pejabat-pejabat yang langsung berhubungan dengan pengucuran kredit kepada pengusaha keturunan Cina itu. Kasus korupsi dan kolusi ini ditutup dengan penahanan para pejabat bank yang terkait dengan pengucuran kredit dan pengusaha keturunan Cina pembobol bank.

Dalam proses pemidanaan, pengusaha keturunan Cina pelaku pembobol bank itu berhasil kabur dengan cara yang amat memalukan dan menorehkan aib di kening para penegak keadilan di Indonesia. Hal ini memicu kemarahan masyarakat. Ketidakpuasan dan demonstrasi menuntut tanggung jawab moral para pejabat tinggi yang terkait dengan kolusi dan korupsi, serta kaburnya pengusaha keturunan Cina itu, merebak di manamana. Para demonstran menuntut mundurnya ketua DPA, pemberi rekomendasi, ketua BPK yang dianggap mengetahui seluk-beluk pengucuran kredit, dan menteri kehakiman, sebagai pihak yang dianggap paling bertanggung jawab dalam proses pemidanaan terhadap pengusaha keturunan Cina tersebut. Di samping itu, para demonstran juga menuntut penangkapan kembali dengan segera buronan tersebut. Namun, semua ini tidak pernah menjadi kenyataan. Para pejabat tinggi itu tidak mendapat sanksi hukum dan tidak mengundurkan diri. Sementara itu, sang buronan yang kabur tetap raib tidak diketahui di mana ia berada (lihat Forum Keadilan No. 23, Tahun IV, 26 Februari 1996 dan No. 4, Tahun V, 3 Juni 1996 serta Tiras, no. 19, Tahun II, 5 Juni 1996).

Peristiwa kolusi, korupsi, dan pembusukan hukum di atas tidak mudah dikesampingkan begitu saja oleh seorang pembaca ketika ia membaca cerpen Parta Krama karena apa yang terdapat dalam cerpen Parta Krama kejadiannya mirip dengan peristiwa di atas. Di dalam cerpen Parta Krama, Drs. Herdjuna, pejabat senior Bank Jonggringslaka juga melakukan 
persekongkolan dengan seorang pengusaha keturunan Cina bernama A Jouw A Jouw agar istrinya mendapatkan mobil BMW seri 7 dan kalung berlian rancangan rumah mode Bulgari. Untuk keperluan itu, Drs. Herdjuna sebagai pejabat senior Bank Jonggringslaka harus mengatur kucuran kredit kepada A Jouw A Jouw sebesar puluhan miliar rupiah. Pada akhir cerita, ketika praktik persekongkolan itu terbongkar, melalui lembaga peradilan tertentu yang beritanya diekspos surat kabar, Drs. Herdjuna dan A Jouw A Jouw dibebaskan dari segala tuduhan kolusi dan korupsi.

Di dalam tulisan ini, sebelum pembicaraan dilanjutkan, terlebih dahulu akan dikemukakan lakon wayang Parta Krama sebagai latar belakang penciptaan cerpen Parta Krama untuk melengkapi kutipan cerita Parta Krama yang ada pada paro awal cerpen Parta Krama. Kisahnya sebagai Berikut.

Dari sekian banyak perkawinan yang pernah dilakukan Arjuna, perkawinan yang paling megah, paling mewah, dan paling agung adalah perkawinan yang dijalaninya dengan Sembadra (Lara Ireng). Kemegahan, kemewahan, dan keagungan perkawinan ini ditunjukan dengan berbagai persyaratan pengantin yang harus dipenuhi Arjuna, seperti: (1) Balai Kencana bertiang 800; (2) Pohon Klepu Dewandaru-Janandaru; (3) Parijata Kencana; (4) Kereta Jatisura bersaiskan dewa sebagai kendaraan pengantin; (5) Kebo Andanu berjumlah empat puluh ekor dengan kaki berwarna putih sebagai tontonan perhelatan; (6) Kera putih untuk tontonan perhelatan; (7) Gamelan Lokananta untuk memeriahkan perhelatan; dan (8) Tujuh orang bidadari sebagai pelayan pengantin.

Untuk mengadakan semua persyaratan ini, Arjuna meminta bantuan Bhima. Bhima dimintai bantuan untuk mencarikan Balai Kencana bertiang delapan ratus, Kereta Jatisura, Kebo Andanu, dan kera putih. Arjuna sendiri dengan diiringi Semar berupaya mencari benda-benda kedewataan, seperti Gamelan Lokananta, Pohon Klepu Dewandaru-Janandaru, dan Parijata Kencana.

Singkat cerita, semua persyaratan pengantin yang bersifat duniawi dan surgawi berhasil diwujudkan Arjuna. Pada saat temu pengantin, Batara Indra turun dari kahyangan menggenapi persyaratan pengantin, yaitu dengan membawa tujuh orang bidadari yang akan bertindak sebagai pelayan pengantin Arjuna dan Sembadra. Di samping itu, Batara Indra juga menyatakan kesediaannya untuk menjadi sais yang akan mengendalikan 
Kereta Jatisura. Dengan demikian, sempurnalah perkawinan Arjuna dengan Sembadra sebagai sebuah perkawinan yang megah, mewah, dan agung.

Sebagaimana halnya dengan permasalahan kolusi, korupsi, dan pembusukan hukum, lakon Parta Krama juga tidak dapat diabaikan begitu saja oleh seorang pembaca ketika ia membaca cerpen Parta Krama. Di dalam cerpen Parta Krama, Drs. Herdjuna (personifikasi Arjuna), melalui perspektif narator, digambarkan sebagai seorang pejabat senior sebuah bank ternama bernama Jonggringslaka. Di dalam cerita wayang, Arjuna adalah salah seorang kesatria Pandawa yang berdiam di Madukara. Nama Bank Jonggringslaka bukan Madukara tampaknya dipergunakan dengan sengaja oleh narator untuk membuat analogi bank yang kedudukannya (paling) tinggi dalam hierarki bank-bank. Nama Jonggringslaka mengingatkan pembaca akan kahyangan Jonggringslaka, tempat bersemayam Batara Guru yang di dalam cerita wayang tempat itu diceritakan tidak dapat dijangkau oleh sembarang orang karena letaknya sangat tinggi, sangat jauh, dan perjalanan yang harus ditempuh untuk menuju tempat itu sangat sulit.

Mungkin, bank yang dimaksud adalah bank sentral atau bank-bank yang memiliki kedudukan setara dengan bank tersebut. Jika dugaan ini benar, sampai di sini, identitas Drs. Herjuna tersingkap, yaitu bahwa ia adalah pejabat senior bank sentral atau bank-bank yang setara dengan bank sentral. Dengan sendirinya, dengan kedudukannya itu, ia mempunyai kewenangan turut menentukan jumlah kredit yang layak diberikan banknya kepada para nasabah.

Salah seorang nasabah Bank Jonggringslaka bernama A Jouw A Jouw, seorang warga negara keturunan Cina mengetahui kewenangan Drs. Herjuna ini. Karena ia ingin mendapatkan kucuran kredit berjumlah puluhan miliar rupiah, dan dengan cara yang wajar ia tidak akan dapat menrima kucuran kredit sejumlah yang diinginkannya, A Jouw A Jouw merancang kiat untuk mewujudkan keinginannya itu. Ia pun menjalin kontak dengan istri Drs. Herdjuna. A Jouw A Jouw yang kaya akan trik dan siasat seperti Begawan Drona menemukan kiat yang cukup jitu. Nyonya Lies Herdjuna yang sudah lama memimpikan memiliki mobil BMW seri 7 dan kalung bertatahkan berlian keluaran rumah mode Bulgari seperti kepunyaan Nyonya Sri Klantangmimis yang istri seorang dirjen dari sebuah departemen yang sangat basah, didekati dan dibujuk agar bersedia membantunya merayu Drs. Herdjuna agar banknya bersedia mengucurkan kredit sebesar jumlah yang 
diinginkan A jouw A Jouw akan menyediakan barang-barang mewah yang diinginkan Nyonya Lies Herdjuna di atas.

Pada mulanya, Drs. Herdjuna ragu-ragu terhadap bujukan istrinya. Namun, karena istrinya terus-menerus mendesaknya, ia menjadi tergoda untuk mengabulkan permintaan istrinya. Lebih-lebih, setelah ia ingat bahwa namanya adalah Herdjuna yang tidak lain adalah Arjuna. Oleh sebab itu, didorong romantisme epos, Drs. Herdjuna yang sudah mengidentikkan dirinya sebagai Arjuna menganggap permintaan istrinya terasa wajar dan masuk akal. Ia membandingkan permintaan istrinya. Lies dengan permintaan Lara Ireng kepada Arjuna.

Dia lantas ingat pula bagaimana Sri Kresna menghibur dan membesarkan hati Arjuna. Bahwa permintaan Lara Ireng untuk seorang Arjuna yang mahasakti bukan merupakan permintaan yang muskil; bahwa permintaan itu adalah permintaan seorang yang sangat dicintainya; dan bahwa permintaan itu adalah pernyataan biasa dan wajar dari seorang perempuan untuk menguji kebesaran cintanya. Herdjuna lantas tersenyum mengingat akan hal itu .... Tiba-tiba Herdjuna meninju pelan-pelan kayu bingkai jendela kantornya. Eeeit, lhadalahh...jangan sebut aku laki-laki.

Akhirnya, permohonan kredit yang diajukan oleh A Jouw A Jouw dapat disetujui tim evaluasi proposal Bank Jonggringslaka. A Jouw A Jouw menerima kucuran kredit berjumlah puluhan miliar rupiah pada saat pemerintah tengah memberlakukan kebijakan pengetatan kredit. Sebagai ucapan terima kasih, A Jouw A Jouw mengirimkan mobil BMW seri 7 dan kalung berlian keluaran rumah mode Bulgari sebagaimana yang pernah ia janjikan kepada Ny. Lies Herdjuna.

Melalui perspektif narator, pencerita dengan memanfaatkan gaya ironi secara tersirat menertawakan tindakan yang dilakukan secara sok heroik. Permintaan istri kepada seorang suami untuk melakukan penyelewengan dikatakannya sebagai ujian cinta. Permintaan Lies yang bersifat kolulatif, dirasakan dan ditanggapi Drs. Herdjuna sebagai permintaan yang wajar dan harus dipenuhi untuk membuktikan kelelakiannya sebagaimana Arjuna memenuhi delapan macam permintaan Sembadra.

Berdasarkan hal di atas, dapat dikatakan bahwa di dalam cerpen Parta Krama narator telah memperlakukan secara kreatif repertoire-nya, yaitu lakon wayang Parta Krama. Cerpen Parta Krama tampak berupaya 
mengolah kembali konvensi lakon Parta Krama menjadi idiom-idiom kehidupan sehari-hari yang lebih kontekstual bagi pembacanya. Hal ini juga dapat dilihat melalui perspektif tokoh. Nama-nama tokoh cerpen Parta Krama sebagian besar adalah nama-nama tokoh wayang seperti Drs. Herjuna (Arjuna), Sri Klantangmimis (Klantangmimis), Pak Siwa, Pak Wisnu, Pak Brahma, dan Pak Narada. Nama-nama ini dibaurkan dengan nama-nama Lies dan A Jouw A Jouw menjadikan Parta Krama tidak terasa imitatif.

Penjelasan mengenai identitas tokoh dapat dipahami sebagai strategi yang tampaknya merupakan upaya untuk mendefamiliarisasikan apa-apa yang sudah familiar. Arjuna (Herdjuna), tokoh terkemuka keluarga Pandawa yang kesatria jantan mahasakti dan jago para dewa, di dalam cerpen, diberi identitas sebagai seorang pejabat senior Bank Jonggringslaka bukan Bank Madukara. Sri Klantangmimis diberi identitas sebagai istri seorang dirjen dan memiliki profesi sebagai pedagang berlian.

Nama Sri Klantangmimis cukup ambivalen. Nama ini dapat dianggap sebagai nama utuh Sri, tetapi juga dapat ditafsirkan sebagai Sri yang bersuamikan Klantangmimis. Tafsiran yang kedua barangkali lebih tepat karena dalam cerita wayang, Klantangmimis adalah sistem nama lakilaki. Nama ini biasa dipergunakan untuk menyebut nama lain "Buta Cakil". Jika benar demikian, yang ditamsilkan sebagai "Buta Cakil", tokoh pembuat onar dan licik adalah sang dirjen. Akan tetapi, apabila interpretasi pertama yang benar, Sri sendirilah si "Buta Cakil" itu. Lepas dari ketepatan dua interpretasi di atas, penyebutan "Buta Cakil" untuk seorang dirjen atau seorang istri dirjen dari perspektif narator dapat dipandang sebagai sinisme narator terhadap perilaku pejabat tinggi dan keluarganya yang suka memamerkan kekayaannya sebagaimana halnya dengan Sri Klantangmimis.

Nama-nama deposan Bank Jonggringslaka juga bukan nama-nama sembarangan. Siwa, Wisnu, Brahma, dan Narada merupakan nama-nama yang sangat berwibawa dalam cerita wayang. Ketiga nama pertama adalah trimurti yang merupakan manifestasi dewa yang tertinggi, sedangkan nama terakhir, Narada, dikenal sebagai orang kedua dalam hierarki para dewa setelah Batara Guru. Dengan dukungan para deposan yang berkualifikasi sangat hebat ini, Bank Jonggingslaka menjadi bank yang sangat penting dan tanpa tanding. Sehubungan dengan itu, tampaknya tidak berlebihan jika di muka disebutkan bahwa Bank Jonggingslaka adalah bank sentral atau bank yang mempunyai kedudukan setara dengan bank sentral. 
Mestinya, dengan kedudukannya yang seperti ini Bank Jonggrislaka tidak mudah ditaklukkan oleh para debitor yang tidak bertanggung jawab. Akan tetapi, karena pribadi yang ada di belakang bank tersebut mudah goyah dan mudah dipengaruhi debitor yang tidak segan-segan memberikan sejumlah upeti jika permohonan kreditnya dikabulkan, bank ini menjadi mudah ditaklukkan.

Sebagaimana diungkapkan di atas, Bank Jonggringslaka tidak keberatan mengucurkan kredit puluhan miliar rupiah kepada A Jouw A Jouw karena A Jouw A Jouw dapat memenuhi keinginan Nyonya Lies Herdjuna, istri salah eorang pejabat senior bank tersebut. Di sini, tampak bahwa narator ingin mengemukakan betapa rapuhnya sistem perbankan di Indonesia.

Kendati Drs. Herdjuna dan A Jouw A Jouw jelas-jelas telah melanggar hukum, lembaga peradilan pun tidak mudah menyeret mereka ke muka peradilan. Begitu mudah, seseorang yang mempunyai kekuasaan mengelakan diri dari sanksi hukum. Drs. Herdjuna dan A Jouw Ajouw yang nyata-nyata melanggar hukum karena melakukan kolusi dan korupsi di Bank Jonggringslaka diputus bebas karena dinyatakan tidak bersalah. Anehnya, pembebasan ini, di kalangan perbankan justru disambut dengan perasaan lega bukan kecewa. Hal ini membuktikan bahwa kolusi dan korupsi semacam itu sudah dianggap sebagai hal yang wajar dan biasa.

Berita mengenai manipulasi Drs. Herdjuna dan A Jouw A Jouw ditampilkan sebagai headline surat kabar Nurani Bangsa secara kebetulan dimuat bersama dengan berita kemenangan perkumpulan wayang orang "Hambeksa Arta" pimpinan Nyonya Lies Herdjuna dalam Festival Wayang Orang Amatir Seluruh Indonesia. Di dalam festival itu, perkumpulan wayang orang yang seluruh anggotanya adalah para karyawan Bank Jinggringslaka menjadi juara pertama. Adapun lakon yang mereka mainkan adalah Parta Krama dengan Nyonya Lies Herdjuna sebagai pemeran Sembadra.

Halaman depan dari koran Nurani Bangsa beberapa bulan kemudian, memuat berita-berita sebagai berikut: I. Drs. Herdjuna dan A Jouw A Jouw dibebaskan dari segala tuduhan kolusi yang terjadi di Bank Jonggringslaka. II. Masyarakat perbankan merasa lega dengan keputusan itu. III. Festival Wayang Orang Amatir Seluruh Indonesia telah memilih perkumpulan Hambeksa Arta, yang terdiri dari karyawan-karyawati Baank Jonggringslaka, sebagai 
pemenang pertama. Lakon yang mereka pilih adalah Parta Krama dengan Nyonya Lies Herdjuna sebagai pemegang peran Sembadra.

Nama Hambeksa Arta yang kurang lebih berarti"menarikan atau mempermainkan uang"--spekulasi, korupsi, atau manipulasi--menjadi trade mark para karyawan Bank Jonggringslaka. Bahkan, jika dibandingkan dengan keadaan serupa yang ada di bank-bank lain (perkumpulan wayang orang yang lain), apa yang terjadi di Bank Jonggringslaka tetap paling unggul (juara pertama). Kebiasaan hambeksa arta ini dianggap wajar dan biasa saja walaupun sudah berlangsung sebagaimana layaknya sebuah festival. Yang paling setia merekam dan merenungkan semua peristiwa ini hanyalah surat kabar Nurani Bangsa. Dengan kata lain, hanya hati nurani atau nurani bangsalah yang (masih) dapat melihat bahwa sesuatu telah membusuk (hukum, moral, harga diri, dsb.).

Melalui perspektif pembaca, apa yang disampaikan narator dalam cerpen Parta Krama dapat dipahami sebagai upaya narator untuk mempertegas pendiriannya mengenai keharusan dan keberanian menyatakan something is rotten in the state jika di dalam negara benar-benar ada sesuatu yang membusuk. Di samping itu, narator juga ingin mengungkapkan kendala-kendala penerapan pola high living (kehidupan luhur) yang di tengah-tengah masyarakat yang dikendalikan oleh uang (arta) menjadi sangat berat karena kekayaan dan uang adalah segala-galanya (perhatikan apa yang telah dilakukan Drs. Herdjuna, A Jouw A Jouw, dan Nyonya Lies).

Cerpen Parta Krama adalah sebuah parodi dan kritik sosial tanpa pemihakan, tanpa maksud menggurui, serta tanpa tendensi menghakimi. Parta Krama mengalir begitu saja membawa muatannya tanpa campur tangan pengarang. Dengan demikian, dapat dikatakan bahwa Parta Krama berbicara mengenai dirinya sendiri. Dari sini, terlihat bahwa pengarang secara ketat memelihara distansi dengan apa yang dikemukakannya melalui cerpen Parta Krama.

Pilihannya terhadap gaya "main-main" atau guyon parikena menjadikan Parta Krama tetap terasa cair dan tidak tegang meskipun harus mengungkapkan probem-problem aktual yang pada masa penulisan cerpen itu amat serius dan sensitif. Semua ini menyebabkan cerpen Parta Krama signifikan. 


\section{Simpulan}

Berdasarkan pembahasan terhadap cerpen Parta Krama, dapat disimpulkan bahwa cerpen Parta Krama telah secara kreatif menginterpretasi, mereduksi, dan mentransformasikan repertoire-repertoirenya, seperti lakon wayang Parta Krama dan sistem norma-norma sosiokultural yang melibatkan praktik kolusi, korupsi, dan pembusukan hukum. Semua ini ditunjukkah melalui perspektif narator, tokoh cerita, dan pembaca dengan memanfaatkan strategi yang salah satu fungsinya adalah mendefamiliarisasikan apa-apa yang sudah familiar. Dengan cara demikian, cerpen Parta Krama bukan imitasi lakon wayang Parta Krama. Tegangan antara Parta Krama dan bukan Parta Krama ini, dari pespektif pembaca justru melahirkan efek estetik.

\section{DAPTAR PUSTAKA}

Ajidarma, Seno Gumira. 1997. "Satu Jam di New Yock: Umar Kayam dalam Secangkir Kopi dan Sepotong Donat". Makalah Seminar Seni, Budaya, Ilmu Pengetahuan menyabut Purna Bakti Prof. Dr. Umar Kayam. Yogyakarta: PPKPS Universitas Gadjah Mada.

Dhakidae, Daniel. 1997 "Kekuasaan dan Perlawanan dalam Novel Para Priyayi". Makalah Seminar Seni, Budaya, Ilmu Pengetahuan menyabut Purna Bakti Prof. Dr. Umar Kayam. Yogyakarta: PPKPS Universitas Gadjah Mada.

Faruk. 1996. “Umar Kayam di Dunia Sastra”. Jawa Pos, 12 Mei 1996.

Forum Keadilan. 1996. "Episode Kedua Kisa Edi Tansil: Tuduhan Suap". Forum Keadilan, No. 23 Tahun IV, 26 Februari 1996, h. 22--33.

1996. "Perburuan Jejak Manusia Rp 1,3 Triliun". Forum Keadilan, No. 4 Tahun V, 3 Juni 1996, h. 21--24.

Holub, Robet C. 1989. Reception Theory: A Critical Introduction. London: Routledge. 
Iser, Wolfgang. 1987. The Act of. Reading: A Theory of Aesthetic Response. Baltimore: The Johns Hopkins University Press.

Kaya, Umar. 1995. Sri Sumarah. Jakarta: Pustaka Jaya.

1996. "Lebih Jauh dengan Umar Kayam”. Kompas, 5 Mei 1996.

1996. “Sphinx”. Kompas, 15 September 1996.

1996 “Raja Midas”. Kompas, 22 Desember 1996.

1997. “Parta Krama”. Kompas, 23 Februari 1997.

1997. "Something is Rotten in the State of Denmark". $D \& R$, No. 33/XXVIII/5 April 1997.

1997. "Sistem Kekuasaan Kita Masih Feodal". Wawancara dengan Umar Kayam. Forum Keadilan, No. 4 Tahun VI, 2 Juni 1997.

1997. "Drs. Citraksi \& Drs. Citraksa”. Kompas, 15 Juni 1997.

Kuntowijoyo, 1997. "Para Priyayi sebagai Novel Sejarah". Makalah Seminar Seni, Budaya, Ilmu Pengetahuan menyabut Purna Bakti Prof. Dr. Umar Kayam. Yogyakarta: PPKPS Universitas Gadjah Mada.

Ricoeur, Paul. 1991. Tekst en Betekenis: Opstellen over de Interpretatie van Literatuur. Baarn: Ambo bv.

Tiras. 1996. "Gelombang Demo Menggoyang Pejabat: Raibnya Edy Tansil Melahirkan Sejumlah Tuntutan Masyarakat". Tiras, No. 19/Tahun II/5 Juni 1996. 